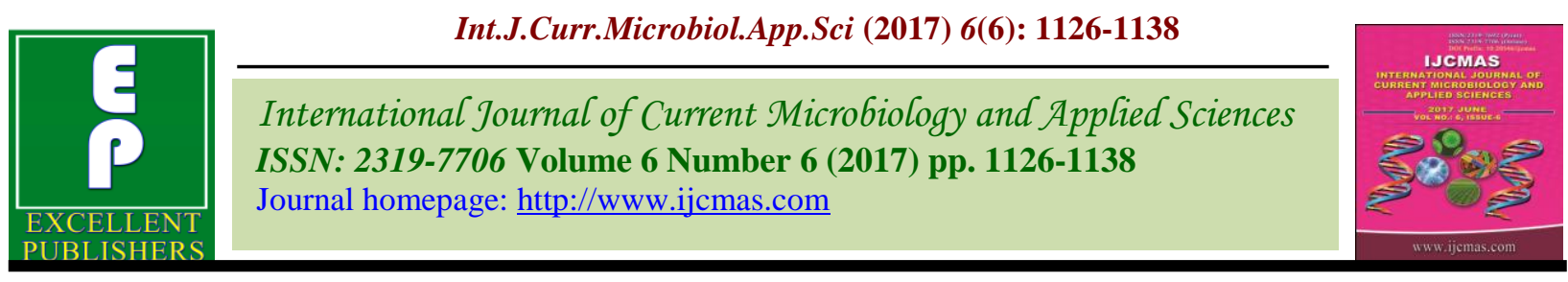

Review Article

https://doi.org/10.20546/ijcmas.2017.606.131

\title{
Management Strategies of Sun Burn in Fruit Crops-A Review
}

\author{
Narayan Lal ${ }^{1 *}$ and Nisha Sahu ${ }^{2}$ \\ ${ }^{1}$ ICAR-NRC on Litchi, Muzaffarpur, Bihar, India \\ ${ }^{2}$ ICAR-NBSSLUP, Division of RSA, Nagpur, MH, India \\ *Corresponding author
}

\begin{tabular}{|c|c|}
\hline & A B S T R A C T \\
\hline $\begin{array}{l}\text { K e y w o r d s } \\
\text { Sun burn, } \\
\text { Cultivars, } \\
\text { Fruit bagging, } \\
\text { Suppressants. } \\
\end{array}$ & \multirow{3}{*}{$\begin{array}{l}\text { Sunburn injury is common on fruits in due to high solar radiation levels and } \\
\text { air temperatures, low relative humidity, and high elevations. The incidence } \\
\text { and severity of sunburn depends upon climatic factor, cultivars, hormonal, } \\
\text { nutritional and soil moisture. Fruit production losses due to sunburn may be } \\
6 \text { to } 30 \text { per cent depending on seasons and the type of fruit. Grower must } \\
\text { follow best management practices to minimise sunburn and grow tolerant } \\
\text { cultivars, efficient irrigation, appropriate canopy management, cover or } \\
\text { intercropping, over tree sprinkler, shade netting, fruit bagging, suppressants } \\
\text { (Kaolin or calcium carbonate) and chemical protectants. }\end{array}$} \\
\hline Article Info & \\
\hline $\begin{array}{l}\text { Accepted: } \\
\text { 17 May } 2017 \\
\text { Available Online: } \\
\text { 10 June } 2017\end{array}$ & \\
\hline
\end{tabular}

\section{Introduction}

Sunlight is the primary source of energy used in photosynthesis by plants to convert carbon dioxide and water into carbohydrates, which the plant uses to make stems, leaves, roots, and fruits. Without this source of energy, life is not possible. Besides, sun light up to certain level is very much helpful to improve quality and production, and also reduces incidence of pest and diseases. If the intensity of sun light is beyond the optimum, plants suffer from many physiological problems and sun burn is one of them. Sunburn injury is common on fruits in due to high solar radiation levels and air temperatures, low relative humidity, and high elevations. Ultraviolet (UV) radiation is greater at higher elevations and is the greatest contributor to damage. Excess absorbed energy is the greatest contributor to cell death and sunburn. The incidence and severity of sunburn depends upon climatic factor, cultivars, hormonal, nutritional and soil moisture (Schrader et al., 2003). The damage caused due to sun burning which occurs up to 0.9-19.13\% in different varieties (Singh et al., 2012). Sunburn occurs mainly where air temperature and the number of sunny hours are high during the ripening period. Sunburn also occurs when cool or mild weather is abruptly followed by hot, sunny weather. Severe sunburn alters the cuticle even more, and damages both the epidermal and sub epidermal tissues. Cell walls get thicker. Intercellular phenols increase, and the structures of plastids and thylakoids change (Barber and Sharpe, 1971; Andrews and Johnson, 1996, 1997).Concurrent water stress can intensify the damage (Brooks and Fisher, 1926; Ware, 1932; Meyer, 1932; Whittaker 
and McDonald, 1941; Moore and Rogers, 1942; Barber and Sharpe, 1971). Some plant pathogens such as Alternaria tenuis, Physalospora obtusa, Monilinia fructicola (=Monilia fructicola), Monilinia laxa (=Monilia laxa), Monilinia fructigena (=Monilia fructigena), Glomerella cingulata, and Venturia inaequalis can infect the fruit through the injured epidermal tissue, making it unmarketable (Holb, 2002 and Leeuwen et al., 2000, 2002). The quality of the fruits is affected by sun burn (Schrader et al., 2001 and Racskó et al., 2005). Therefore, sunburn can cause serious economic losses in many crops with heavy losses in apple (Brooks and Fisher, 1926; Ware, 1932; Meyer, 1932; Whittaker and McDonald, 1941; Moore and Rogers, 1942; Barber and Sharpe, 1971; Bergh et al., 1980; Simpson et al., 1988; Warner, 1997; Schrader et al., 2001).

\section{Sun burn in fruit crops}

Some modern fruit production techniques can increase the risk of sunburn. Rootstock is becoming popular in fruit production and dwarfing rootstocks growing on trellis and using training systems that allows direct sunlight to penetrate throughout the canopy of tree and this can increase fruit yields and improve colour development but can increase the risk of sunburn. Fruit production losses due to sunburn may be 6 to30 per cent depending on seasons and the type of fruit. Estimates of recent losses in susceptible orchards vary from 10 to 40 per cent in Granny Smith apples, 15 to more than 50 per cent in Gala apples, 10 to 25per cent in Pink Lady apples and 10 to 15 per cent in Williams's pears. When air temperatures rise above 30 to $35^{\circ} \mathrm{C}$ during the day time, photosynthesis is likely to slow which will reduce potential fruit yield. The energy of sunlight can cause damage to the sun-exposed surface of the fruit. Sunburn is more due to the direct force of the sun than air temperature. The temperature of sun-exposed of apples is often 10 to $18^{\circ} \mathrm{C}$ higher than the maximum shaded air temperature (Schrader $e t$ al., 2003a). Unlike leaves, many types of fruits like apples and pears have very limited cooling capacity via transpiration from the skin of the fruit. Heat stress on fruit can also increase the incidence of other skin disorders in apples e.g. Lenticel Marking, Bitterpit, Splitting and Watercore (Schrader et al., 2003b). Sunburn risk is also affected by tree factors, like variety, canopy density and fruit size (Schrader et al., 2003b). Larger fruit are more likely to sunburn than smaller fruit. Position of fruit on the tree also affects sunburn risk. For example, fruit at the outer edge of the canopy and fruit positioned with a westerly aspect will be more prone to sunburn. Sun burn in apple are entry points for fungi such as Alternaria spp. (Barber and Sharpe, 1971; Bergh et al., 1980; Simpson et al., 1988; Holb, 2002; Leeuwen et al., 2000, 2002). Maximum fruit surface temperatures are normally attained between $2 \mathrm{pm}$ and $5 \mathrm{pm}$, in the hottest part of summer. Fruit damage usually becomes most apparent after a prolonged hot period.

Like human skin, fruit skin can become acclimatised to sun heat. The natural sun protection in apple is associated with the presence of antioxidants and 'heat shock proteins' (Brown, 2009). Fruit that has been exposed to direct sunlight earlier in the season will be more tolerant of direct sunlight and high temperatures later in the season. Apples exposed to ultraviolet radiation and high temperatures will usually reach maximum levels of skin antioxidants and 'heat shock proteins' after about three days. Different types of sunburn (Sunburn necrosis, Sunburn browning and Photo-oxidative sunburn) have been identified and characterised in apples (Schrader et al., 2003b; Felicetti and Schrader, 2008). Sunburn necrosis is caused by heat, when the fruit surface temperature of 
an apple reaches $52 \pm 1^{\circ} \mathrm{C}$ for 10 minutes. Cells die and later a sunken dark brown or black (necrotic) patch may appear. Sunburn browning is the most common type of sunburn and results in a yellow, brown or dark tan patch on the sun-exposed side of the apple. The minimum threshold fruit surface temperature that will cause sunburn browning varies from 46 to $49^{\circ} \mathrm{C}$ for one hour, depending on different varieties. Photooxidative sunburn is found when shaded or partially-shaded apples are moved in to strong direct sunlight and they are prone to sunburn, even when the fruit surface temperature is relatively low (less than $45^{\circ} \mathrm{C}$ ). Often the sunexposed patch of skin will become whitebleached, indicating that skin cells have died. Usually after a few days the patch will gradually become brown and then black and necrotic. Felicetti and Schrader (2008) showed this type of sunburn is mainly due to direct exposure of fruit to visible radiation and it does not require the other main components of solar radiation, i.e. infrared and ultraviolet. Sunburn necrosis in apple happens when the fruit surface reaches $52 \pm 1^{\circ} \mathrm{C}$, which damages the permeability of cell membranes. Sunburn browning happens when the fruit surface reaches $46^{\circ}$ to $49^{\circ} \mathrm{C}$, but sunlight also plays a decisive role in its formation.

It was found that untreated trees gave the highest percentages of sunburn fruits, while generally kaolin and silica gel sprays after fruit setting and before the first anticipated reduced the percentages of fruit sunburn (Aly et al., 2010). Furthermore, it was reported that, plants use several protective mechanisms to avoid sunburn) dissipation of excess energy through the xanthophylls cycle (DemmigAdams et al., 1995 and Muller et al., 2001) induction of antioxidants to minimize oxidative damage (Ma and Cheng, 2003) UV$\mathrm{B}$ attenuation by reflecting pigments (Merzlyak and Solovchenko, 2002) and production of heat shock proteins (Ritenour et $a l$., 2001). Sunburn on fruit surfaces occurs under conditions of both high temperature and high irradiance (Rabinowitch et al., 1974 and Schrader, et al., 2003). Aly et al., (2010) reported that total anthocyanin isolated from apple skin significantly increased with spraying 1 and $2 \%$ kaolin clay and $0.5 \%$ silica gel compared to control and (Dong et al., 1995; Faragher and Chalmers, 1997; Miller and Greene, 2003 and Toye, 1995) also reported that anthocyanin content increased. There may be two different ways that light enhances anthocyanin synthesis and accumulation in apples. One is to increase canopy photosynthesis and assimilate supply to the fruit, and, thus, indirectly stimulate anthocyanin synthesis by providing substrate. Another possibility is that the film treatments directly stimulated anthocyanin synthesis $(\mathrm{Ju}$, et al., 1999).

Sunburn also known as lesion browning or pericarp necrosis is a serious problem in litchi. This disorder is physiologically related with PPO (Poly-phenol Oxidize) activities in litchi and it also varies with cultivars. Sunburn is pronounced in ill managed orchards having sandy or sandy loam soils or light soils receiving/exposed to high temperature $\left(>40^{\circ} \mathrm{C}\right)$ and very less $\mathrm{RH}$ $(<50 \%)$. It is a type of direct thermal injury and in case of higher temperature, the tissue coming in contact/exposure gets sunburnt/ sun scalded. Sunburn problem is also seen more in early ripening cultivars of litchi. Fruits on shaded branches suffer less damage than those more exposed to sun. Lower translocation of calcium in the pericarp region also found to favour sunburn disorder. In case of sunburn light brown blotches appear on the portion of the fruit skin facing direct sun rays. In severe cases more than half of the surface area becomes discoloured, blotchy light brown. The blotches become intense in few days and the blotchy area dries up blocking of 
the aril growth. The symptoms appear more on the south west side than the north-east side as on the latter side fruits remain almost in shade except during early hours of the day, which is not harmful.

Pineapples are susceptible to heat stress and sun damage, which can significantly reduce marketable yield. Extreme sun intensity can limit overall plant production and directly damage fruit. In many cases, damage is not realized until after the fruit is harvested. Early symptoms of sunburn exhibit as yellowing, "bleached" skin that turns pale grey/brown as the tissue deteriorates. This damaged tissue is susceptible to disease and infestation. Internal damage occurs when the fruit overheats and ends up "cooking" on the inside. There are some conditions which increases the risk of sunburn:

Modern intensive orchard production systems on dwarfing rootstocks growing on trellis and, training systems that allow good lightpenetration through the orchard canopy

Fruit positioned with southerly and westerly aspect in direct sunlight

Sudden movement of fruit from shade to strong and direct sunlight

Hot, sunny and calm days

Cool, cloudy weather followed by clear-sky day's greater than $30^{\circ} \mathrm{C}$

Plant water stress on hot days

Convection heat

\section{Management of sunburn in fruit crops}

Grower must firstly follow best management practices to minimise sunburn on fruit before considering investment in expensive sunburn protection products and infrastructure such as spray-on sun protection, shade netting or evaporative cooling. Grower should identify which fruit blocks are more susceptible to sunburn, what control strategies can be employed in each block and which blocks have the best chance of achieving good returns on the additional investment (Brown, 2009). Shade netting and over tree sprinkler cooling systems are best but it has high set-up costs.

\section{Climate ameliorating techniques}

\section{Best Management Practices for sun protection}

\section{Use fruit varieties that are more tolerant of sunburn}

Granny Smith and Royal Gala are considered to be most susceptible. Other apple varieties that are susceptible to sunburn are Jonagold, Braeburn, Golden Supreme, Ginger Gold and Fuji (Evans, 2004). Pink Lady® is more tolerant than Cameo and Honeycrisp (Schrader et al., 2003a).

\section{Schedule irrigations to avoid tree water stress}

Healthy, fully irrigated trees receive the maximum cooling benefit from transpiration. Irrigation scheduling techniques based on weather forecasts and soil moisture measurements should be used to ensure irrigation is well-matched with the crop's water requirements. Irrigation should be used just before or during heat waves to avoid tree stress and sunburn. Proper irrigation helps to create congenial microclimate for fruit production.

\section{Train fruit trees to develop an appropriate canopy}

Fruit crops which are highly susceptible to sun burn should not be trained on the system 
which directly exposes the fruits to sun. Apple and pear fruit sunburn is often associated with thin exposed canopies when branches move under the weight of the developing crop.

Avoid branch movement by training young trees with less fruit developing at the ends of branches and with scaffold branches that can support the fruit load. Supporting the limbs and branches of free standing trees with bands tied two-thirds of the way up the trees.

\section{Avoid excessive summer pruning and leaf stripping}

This is often done to allow light into shaded parts of many fruit trees to enhance colour development. This should be done carefully to avoid limb movements and sudden exposure of fruit to direct sunlight, especially during hot weather.

\section{Cover cropping}

The bare earth and dead vegetation in the inter row space is likely to reflect more sunlight into the orchard canopy than green vegetation. In the hottest part of summer this is likely to increase the heat load on fruit and increase the probability of sunburn. Inter row space should be utilized and grow inter crops as per crop specific. Maize or pigeon pea is most useful in pineapple orchard to protect from sunburn/sunscald.

\section{Improve air movement through the fruit} block

The temperature of fruit skin in direct sunlight is higher than the temperature of the surrounding air. Air movement around the fruit helps to remove some of its heat and tends to equalise the temperature of fruit and air.

\section{Over-tree sprinkler cooling systems}

Over-tree sprinkler cooling systems are designed to reduce sunburn by delivering sprinkled water over the tree canopy to cool fruit during the hottest part of the day. The same cooling systems can be used to enhance colour development of 'red' or 'red-blushed' apples close to harvest. Over-tree sprinkler cooling systems rely on the cooling properties of water to reduce temperature extremes on the fruit's surface. All types of over-tree cooling systems rely to varying degrees on three possible water cooling mechanisms (Evans and Van der Gulik, 2011). These are listed below in order of increasing effectiveness, from least to most effective:

\section{Aerial evaporative cooling}

Orchard air can be cooled by water evaporating from fine droplets as they come from misting sprinklers and travel through the air. This creates cool air currents that move through the orchard by convection. This process is very inefficient and not effective for reducing fruit surface temperatures and sunburn, especially when there is wind.

\section{Hydro-cooling}

Water droplets emitted from the over-tree sprinkler system are cooled through evaporation. The cool water runs continuously over the fruit and the rest of the tree, absorbing and carrying away some of the heat. This can be effective, but it tends to use excessive amounts of water and greatly increase the risk of the orchard floor becoming water logged.

\section{Surface evaporative cooling}

Emitters spray droplets over the tree canopy, thoroughly wetting all surfaces to the point of run-off. Fruit is cooled by water continuously 
evaporating directly from its skin. This is the most efficient way to reduce fruit surface temperatures. In this approach, fruit surface is wet during the day time and water losses can be minimized which was being applied on the orchard floor. Using the same amount of water, evaporation can remove 50 times more heat energy than the heat carried away inflowing water.

Every over-tree sprinkler cooling system should be carefully designed to ensure adequate water can be delivered when and where it is required. The heat energy coming into anorchard in the middle of a hot summer's day $\left(35^{\circ} \mathrm{C}\right)$ is approximately 800 Watts per square metre. The amount of water that can be evaporated with that amount of heat energy is estimated to be about 3.1 litres per second perha. However, heat energy is also carried into the orchard by wind and is estimated to be almost as much as the energy from sunlight, so the flow of water to neutralise the total heat load on the orchard is estimated to be approximately 6.2 litres per second per ha (Evans, 2004).

Aerial evaporative cooling uses application rates up to 6litres per second per ha. Very little or no water reaches the ground. With swirling air currents and wind, water droplet and cool air distribution is often not uniform. This process is not very effective at lowering fruit surface temperatures (Evans and Van der Gulik, 2011).

Hydro-cooling uses application rates that are significantly greater than 6.5 litres per second per ha. The amount of water entering the root zone must be carefully co-ordinated with irrigation to ensure the crop's water needs are met and to prevent waterlogging. Normal irrigation applications should be reduced to take into account the volume of water reaching the orchard floor and entering the root zone. It may be very difficult to prevent waterlogging. The soil surface often becomes saturated, with some runoff (Evans and Van der Gulik, 2011).

Surface Evaporative Cooling uses application rates around6.0 to 6.5 litres per second per ha. This is the most effective way to achieve cooling for sunburn protection while minimising water use.

\section{Shade netting}

Shade netting is made from woven synthetic fibres to provide protection from high radiation. In recent years, its use in horticulture has increased because netting materials that are stronger and longer-lasting. It can be used for at least 10 years under natural sunlight. Netting is used for sun, hail, wind and bird protection. Shade netting reduces the adverse effects of climatic extremes, including intense sunlight, wind and hail. Direct sunlight is the primary cause of sunburn. Shade netting is usually designed to reduce mid-day sunlight by about 20 per cent. This reduces the heat loading on trees and fruit from visible and infrared radiation and reduces the amount of damaging ultraviolet radiation. Different net designs are available providing a range of 12 to 25 per cent reduced sunlight. In some situations wind speeds can be reduced by 50per cent. This reduction varies depending on the type of netting, whether it is gabled or flat and whether or not side netting is used as a windbreak or to exclude birds. Anecdotal evidence indicates that wind could either reduce or increase sunburn. There is a complex interaction between fruit surface temperature, tree water status, humidity and wind.

For example, wind in a well-watered orchard will reduce temperature of sun exposed fruit, however, if drying winds raise tree water demand above a rate that can be supplied by 
the roots, then the tree will become stressed and probably also more prone to sunburn.

\section{Different management under shade netting}

Shade netting increases more vegetative growth and excessive shoot growth could reduce fruit set and fruit skin colour development. However, with well-managed apple trees grown on dwarf and semi-dwarf rootstocks, excessive vigour should not be a significant problem (Middleton, 2010).

It is generally accepted that fruit tree yield is proportional to the amount of sunlight that is distributed and intercepted by leaves. It is likely that shade netting will reduce photosynthesis of fruit trees. However, during most of the growing season and most of the day there is an excess of sunlight for photosynthesis and a 20 per cent reduction of sunlight due to shade netting is unlikely to reduce the yield potential and fruit quality of a well-managed orchard, provided direct sunlight can penetrate evenly throughout the tree's canopy.

Under permanent shade netting, with less wind and sunlight, the orchard floor will stay wetter for longer after rainfall and irrigation. Irrigation applications should be reduced to avoid more wet and humid under shade netting. Low air movement and higher humidity under netting can cause fungal diseases. Bound (2010) found that chemical thinning in apple is more effective under shade netting because of lower light levels.

\section{Fruit bagging}

Bagging of individual fruits or bunch is used to prevent fruit injury by sun light, insects and diseases. Individual fruit bagging was used in apple to obtain a smooth finish of the apples along with uniform, but uncharacteristic, skin color (Mink, 1973; Proctor and Lougheed,
1976). Bagging was found to protect apple fruit from sunlight-dependent types of sunburn. Bagging significantly decreases fruit borer infestation, sunburn, spotted and cracked fruits with slightly decreases in TSS and acidity in litchi. The physical appearance, weight and vitamin-C of fruits were significantly improved under all type of bagging. Bagging with white butter paper bag gave the best result and recorded 30-35 \% less damaged fruit. Bagged fruits produced heavy and longer fruit with 6-16\% more weight over control (Anon, 2015).

\section{Suppressants}

Materials that are sprayed on the fruit to suppress sunburn in fruit tree are called suppressants. At least two classes of suppressants exist. There are white particle films that, by definition, are physical inorganic blockers (Antoniou et al., 2008) that block, reflect and scatter solar radiation. A different class of sunburn suppressant is a sunscreen by definition, as it contains organic chemical absorbing agents to further reduce the intensity of high-energy UV radiation by absorption, in addition to physical inorganic constituents.

The suspensions of tiny, white mineral particles (clay or calcium carbonate) or with wax emulsions can be sprayed onto leaves and fruit to create a film that provides some protection from the effects of sunlight.

\section{Particle film}

The use of reflective particles on fruits has been suggested as a tool to diminish its thermic charge because it reduces the incident radiation that can be absorbed by the fruits (Glenn et al., 2002; 2003, Wuncshe et al., 2004) and thus reduce the incidence of sunburn (Glenn et al., 2002; Gindaba and Wand., 2005; Wand et al., 2006; Colavita, 
2011). Purshade reduces solar stress in crops by protecting the foliage and fruit from damaging ultraviolet (UV) and infrared (IR) radiation while still allowing photosynthesis to occur. The mineral particles form a white film that blocks and reflects some of the direct sunlight to reduce the temperature of fruit surface. The wax-based product forms a film that absorbs some of the damaging UV radiation and reflects a small amount of the incoming radiation. These products must be applied several times during the season to maintain a protective cover on the fruit. All spray-on sun protection products must be applied before severe summer heat wave conditions occur and applications must be maintained throughout the hot season to maintain coverage on the expanding fruit. Resellers usually recommend a minimum of three to four applications, separated by seven to 21 days.

\section{Kaolin based product}

The type of clay used is white kaolin, which has many industrial uses. The kaolin used in clay-based sun protection products has been refined and modified to produce awe table powder which can be mixed with water and sprayed onto foliage and fruit to create a white film that will reflect some sunlight. Glenn and Puterka (2005) reported that they can reduce fruit surface temperatures by up to 5 to $10^{\circ} \mathrm{C}$.

Glenn (2009) reported that clay-based coating unaffected photosynthesis or even increased due to reduced heat stress and better distribution of light to lower shaded parts of the tree canopy under highlight intensities. Clay-based products can be easily washed-off the tree and must be re-applied after rainfall and over-tree sprinkler irrigation and evaporative cooling. Glenn and Puterka (2005) reported that these products can act like an insect repellent in fruit crops.
Kaolin and silica gel have been recommended to lower the temperature of the fruit, thereby reducing sunburn and improving red fruit colour in situation when temperatures are supra optimal (Glenn et al., 2001; Heacox, 1999 and Werblow, 1999).

Kaolin reduces fruit surface temperature by increasing the reflection of visible and ultraviolet light (Glenn, et al., 2001; Wunsche et al., 2004). The effectiveness of Kaolin in reducing sunburn in most cultivars and regions may be more strongly ascribed to the reduction in harmful radiation reaching the fruit surface than to the reductions in surface temperature (Gindaba and Wand, 2005), although the latter would lower the threshold for radiation damage. The same results were found by (Schupp et al., 2002) on apple. Aly et al., (2010) reported that kaolin clay particle film produced labeled reduced in sunburn percentages. The same trend was reported by (Melgarejo et al., 2004) on pomegranate fruits.

\section{Calcium carbonate-based product}

The main active ingredient is high-grade calcium carbonate or crystalline limestone. These products are marketed as a liquid that is mixed with water and sprayed onto crop foliage and fruit to form a thin crystalline layer that reflects some sunlight. There is also a calcium-based fertiliser product which claims good sun protection quality. It is a high-analysis suspension fertiliser, high in calcium $(\mathrm{Ca})$, zinc $(\mathrm{Zn})$, magnesium $(\mathrm{Mg})$, nitrogen $(\mathrm{N})$ and boron (Bo). Ahmed et al., (2011) reported that untreating the grapevines with $\mathrm{CaCO} 3$ or Purshade gave the maximum values of sunburned berries \% (20.5. and 22.3 $\%$, in both seasons 2009 and 2010, respectively). Glenn et al., (2002) reported that crimson Seedless grapevines treated with plant protectants and $\mathrm{CaCO} 3$ were less prone to sunburn damage than untreated ones and 
this is due to reducing both fruit temperature and exposure to UV radiation as Purshade and $\mathrm{CaCO}_{3}$ have been found to reflect UV radiation strongly. Melgarejo et al., (2004) found that sunburn damage of pomegranate fruits was depressed from $21.9 \%$ in untreated control to $9.4 \%$ in the kaolin treated fruits. Curry et al., (2004) reported that anti sunburn compounds effectively reduced solar radiation injury of apple trees. Attra (1999) also reported that Purshade and other plant protectants protected fruits from all stresses by leaving a protective powdery film on the surfaces of the fruits and similar results are also obtained by Melgarejo et al., (2004) and Morsy et al., (2008). Ahmed et al., (2011) found that $\mathrm{CaCO} 3$ and Purshade stimulated plant metabolism through enhancing photosynthesis and formation of plant pigments in favour of enhancing quality of the berries and Glenn et al., (2002) and Morsy et al., (2008) are also reported the same.

\section{Talc-based products}

Hanrahan et al., (2009) reported that sunburn incidence could be reduced in apples by four applications of Invelop ${ }^{\circledR}$ (Luzenac, Greenwood Village, CO), a talc-based particle film product.

\section{Sunscreen}

Another sunburn suppressant is a sunscreen by definition (Antoniou et al., 2008), as it contains organic-chemical absorbing agents in addition to physical inorganic constituents. Carnauba wax, the principal component of this sunscreen (RAYNOX®, Pace International, LLC, Seattle, WA), contains cinnamates that absorb high-intensity UV rays with excitation to a higher energy state (Schrader, 2011), but this excess energy is dissipated by emission of longer wavelength light or relaxation by photochemical processes such as isomerization and heat release. RAYNOX® also contains inorganic components that block, reflect and scatter solar radiation, the main active component of the wax-based product is carnauba wax, which is produced on the leaves of a tropical palm tree and also used in cosmetics and car wax. Small amounts of reflective compounds based on clay are also added. The wax-based product is a liquid emulsion sprayed onto fruit trees to form a clear film that filters out a significant proportion of the damaging ultraviolet radiation and a small amount of the visible and infrared radiation. It has been shown to significantly reduce sunburn browning of apples (Schrader, 2011). It has some insect repellent qualities and the distributors claim it has no negative effect on beneficial insects and mites. The applied product is rain fast and can be used in orchards with overhead sprinklers. It is not compatible with other chemicals and a water softener is required when mixing.

\section{Chemical protectants}

This group includes certain naturallyoccurring metabolites that have shown promise, when sprayed on trees, of protecting fruit from effects of excessive temperatures and/or sunlight. The concept is to increase the concentration of selected metabolites in the fruit and enhance the fruit's ability to avoid damage from stress-induced disorders such as sunburn.

\section{Ascorbic acid}

The ascorbate-glutathione cycle is the central antioxidant system that protects fruit from photo oxidative injury (Ma and Cheng, 2004). One of its key components is ascorbic acid (vitamin C), and its level in the peel is positively correlated with susceptibility of the fruit to sunburn (Andrews et al., 1999). Although sunburn incidence was significantly reduced in 'Fuji' apples, ascorbic acid was not effective in 'Granny Smith' (Andrews et al., 
1999). Even though $4 \%$ concentration reduced sunburn incidence more than lower concentrations, mild phytotoxicity occurred on 'Fuji' fruits as darkening of the lenticels. Although ascorbic acid showed promise for controlling sunburn in some apple cultivars, the suggested amount, the frequency of applications and its price make its use impractical commercially.

\section{Abscisic Acid (ABA)}

Recently, Iamsub et al., (2009) reported significant reductions in the incidence of SB and SN in 'Tsugaru' and 'Sensyu' apples in Japan when they applied pure ABA (S-isomer) at $200 \mathrm{ppm}$ concentration or at 400 or $800 \mathrm{ppm}$ rate as a fertilizer. Along with the reduction of sunburn incidence, ABA treatments reduced lipid peroxidation and increased the total antioxidant capacity, phenolics, ascorbic acid, anthocyanin and chlorophyll content of the peel. From these results, the authors concluded that specific ABA-mediated mechanisms contribute to normal cell functions in apples under elevated solar radiation conditions. Considerably more research is needed to establish whether the physiological changes they observed will reduce sunburn in apples grown in areas with higher temperatures and higher solar radiation than experienced in Japan.

\section{Anti-transpirants}

The use of anti-transpirants can effectively reduce excessive water loss through transpiration under drought stress conditions (Yuanwen, 1992). A product named VaporGard ${ }^{\circledR}$ (MillerChemical and Fertilizer Corp., Hanover, PA), whose active ingredient is poly-1-P menthene, has been sold for years as a sunburn protectant. Yuri et al., (2000) and Schrader et al., (2008) reported no significant effect of VaporGard® on sunburn or 'Fuji' stain, a sunburn-related postharvest disorder (Schrader et al., 2008). Given the fact that transpiration is reduced by an antitranspirant, temperature of leaves and small fruitlets is expected to increase; it is therefore not surprising that VaporGard® did not reduce the incidence of temperature-dependent types of sunburn.

It is concluded that all the available technologies are capable of reducing sunburn, but none alone will completely eliminate it. The sun burn tolerance cultivars of fruit crop must certainly be combined with other means of strategies to minimize sun burn in fruit crops. Grower should identify which fruit blocks are more susceptible to sunburn, what control strategies can be employed in each block and which blocks have the best chance of achieving good returns on the additional investment.

\section{References}

Ahmed, F.F., Mokhtar, M. Shaaban and Ahmed, M.K. Abd El-Aal. 2011. Protecting Crimson Seedless Grapevines Growing in Hot Climates from Sunburn. Res. J. Agri. Biol. Sci., 7(1): 135-141.

Aly, M., Nagwa, Abd El-Megeed and Rehab, M., Awad. 2010. Reflective Particle Films Affected on, Sunburn, Yield, Mineral Composition and Fruit Maturity of 'Anna' Apple (Malusdo mestica) Trees. Res. J. Agri. Biol. Sci., 6(1): 84-92.

Andrews, P.K., Johnson, J.R. 1996. Physiology of sunburn development in apples. Good Fruit Grower, 47(12): 3236.

Andrews, P.K., Johnson, J.R. 1997. Anatomical changes and antioxidant levels in the peel of sunscald damaged apple fruit. Plant Physiol., 114(3): 103.

Andrews, P.K., Johnson, J.R., Fahy, D., and Gish, N. 1999. Sunburn protection in apples with ascorbic acid. Le Fruit Belge, 481: 157-161. (In French)

Anonymous. 2015. Annual Report 2014-15, NRC on Litchi, Muzaffarpur, Bihar.

Antoniou, C., Kosmadaki, M.G., Stratigos, A.J., and Katsambas, A.D. 2008. Sunscreens What's important to know. Eur. Acad. Dermatol. Venereol., 22: 1110-1119. 
Attra, A. 1999. Kaolin Clay for Management of Glassy-winged Sharpshooter in Grapes. Reduced-Risk Pest Control Factsheet, Glassy-winged Sharpshooter images source: "Glassy-Winged Sharpshooter Online Media Kit," University of California, Division of Agriculture and Natural Resources, Communication Services website,

Barber, H.N. and Sharpe, P.J.H. 1971. Genetics and physiology of sunscald fruits. Agric. Meteorol., 8: 175192.

Bergh, O., Franken, J., Zyl E.J., Kloppers Van, F. and Dempers, A. 1980. Sunburn on apples - Preliminary results of an investigation conducted during the 1978/79 season. Deciduous Fruit Grower, 30(1): 822 .

Bound, S. 2010. Effective use of thinning tools. Tree Fruit, Magazine, pp. 6-9.

Brooks, C. and Fisher, D.F. 1926. Some high temperature effects in apples: contrasts in the two sides of an apple. J. Agr. Res., 32(1): 123.

Brown, G. 2009. Minimising sunburn damage of fruit. Australian Fruit grower (magazine), February, 3(1); 14-18, Apple and Pear Aust. Ltd.

Colavita, G.M., Blackhall, V. And Valdez, S. 2011. Effect of kaolin particle films on the temperature and solar injury of pear fruits. Acta Hort., 909: 609-615.

Curry, E.A., Baer, D. and J. Young, 2004. XRay Microanalysis of Apples Treated with Kaolin Indicates Wax-Embedded Particulate in the Cuticle. Acta Horticulture Proceedings, 636: 497-503.

Demmig-Adams, B., Adams, W.W. Logan, B.A. and Verhoven, A.S. 1995. Xanthophyll cycle dependent energy dissipation and flexible photosystem II efficiency in plants acclimated to light stress. Australian J. Plant Physiol., 22: 249-260.

Devlin, R.M. and F.H. Withdam. 1983. Plant Physiology. 4th Ed. CBS Publishers and Distributors. Delhi- India Ployezo. pp: 50-55.
Dong, Y.H., Kootstra, D. Witra, Lister, C. and Lancaster, L. 1995. Postharvest stimulation of skin color in 'Royal Gala' apple. J. Am. Soc. Horticult. Sci., Pp. 95100.

Evans, R.G. and van der Gulik, T.W. 2011. Irrigation for Microclimate Control, Chap. 29. L. Stetson, editor. Irrigation. 6thEdition. The Irrigation Association. Falls Church, VA.

Evans, R.G. 2004. Energy balance of apples under evaporative cooling. Transact. Am. Soc. Eng., 47(4): 1029-1037.

Faragher, J.D. and Chalmers, D.J. 1997. Regulation of anthocyanin synthesis in apple skin, Involvement of phenylalanine ammonialyase. Aus. J. Plant Physiol., 4: 133-141.

Felicetti, D.A. and Schrader, L.E. 2008. Photooxidative sunburn of apples: Characterization of a third type of apple sunburn. Int. J. Fruit Sci., 8(3): 160-172.

Gindaba, J. and Wand, S.J. 2005. Comparative effects of evaporative cooling, kaolin particle film and shade net on sunburn and fruit quality in apples. HortSci., 40(3): 592-596.

Glenn, D.M. and Puterka, G.J. 2005. Particle Films: A New Technology for Agriculture. In Horticultural Reviews, Volume 31. Edited by Jules Janick. John Wiley \& Sons, Inc.

Glenn, D.M. 2009. Particle film mechanisms of action that reduce the effect of environmental stress in "Empire" apple. J. Amer. Soc. Hort. Sci., 134(3): 314-321.

Glenn, D.M., A. Erez, G.J. Puterka and P. Gundrum. 2003. Particle films affect carbon assimilation and yield in 'Empire' apple. J. Amer. Soc. Hort. Sci., 128: 356362.

Glenn, D.M., Prado, E., Erez, A. McFerson, J.R. and Puterka, G.J. 2002. A reflective processed kaolin particle film affects fruit temperature, radiation reflection and solar injury in apple. J. Amer. Soc. Hort. Sci., 127: 188-193.

Glenn, D.M., Puterka, G.J., Drake, S.R. and Boughs, T.R. 2001. Particle film 
application influences apple leaf physiology fruit yield and fruit quality. $J$. American Soc. Horticultural Sci., 126: 175-181.

Hanrahan, I., Schmidt, T. R. and McFerson, J. 2009. Comparison of commercial sunburn protection products. HortSci., 44: 1084 1085. [Abstract]

Heacox, L. 1999. Powerful particles. Amer. Friut Gower, 16-17.

Holb, I. 2002. Az Alma ventúriás varasodása: biológia, előrejelzés és védekezés. Szaktudás Kiadó Ház, Budapest, pp. 144.

Iamsub, K., Sekozawa, J., Sugaya, S., Gemma, H., and Kamuro, J. 2009. Alleviating sunburn injury in apple fruit using natural and fertilizer forms of S-abscisic acid and its underlying mechanism. J. Food Agric. Environ., 7: 446-452.

Ju, Z., liu, C., Yuan, Y., Wang, Y. and Liu, G. 1999. Coloration potential, anthocyanin accumulation and enzyme activity in fruit of commercial and their F1 Progeny. Scientia Horticulturae, 79: 39-50.

Leeuwen, Van, G.C.M., Holb, I.J. and Jeger, M.J. 2002 Factors affecting mummification and sporulation of pome fruit infected by Moniliafructigena in Dutch orchards. Plant Path., 51: 787-793.

Leeuwen, Van, G.C.M., Stein A., Holb I.J., Jeger M.J. 2000. Yield loss in apple caused by Monilia fructigena (Aderh. \& Ruhl.) Honey, and spatiotemporal dynamics of disease development. Eur. J. Plant Path., 106: 519-528.

Ma, F. and Cheng, L. 2003. The sun-exposed peel of apple fruit has higher xanthophylls cycledependent thermal dissipation and antioxidants of the ascorbate-glutathione pathway than the shaded peel. Plant Sci., 165: 819-827.

Ma, F. and Cheng, L. 2004. Exposure of the shaded side of apple fruit to full sun leads to up-regulation of both the xanthophyll cycle and the ascorbate-glutathione cycle. Plant Sci., 166: 1479-1486.

Melgarejo, P., Martinez, J.J., Hernandez, F., Martinez-Font, R., Barrows, P. and Erez, A. 2004. Kaolin treatment to reduce pomegranate sunburn. Scientia Horticulture, 100(1-4): 349-353.

Merzlyak, M.N. and Solovchenko, A.E. 2002. Patterns of pigment changes in apple fruits during adaptation to high sunlight and sunscaled development. Plant Biochem. Physiol., 40: 679-684.

Meyer, A. 1932. Comparative temperatures of apples. Proc. Am. Soc. Hort. Sci., 28: 566-567.

Middleton, S. 2010. Manage apples under netting. Tree Fruit (magazine). June 8-9.

Miller, S.S. and Greene, G.M. 2003. The use of reflective film and ethephon to improve red skin color of apples in the MidAtlantic region of the United States. HortTechnol., 13(1): 90-99.

Mink, G.I. 1973. The apple industry in Japan. HortSci., 8: 81-86.

Moore, M.H. and Rogers, W.S. 1942. Sun scald of fruits. East Malling Res. Sta. Rept., pp. 5053.

Morsy, M., Abd El-Aal, A.M.K. and Abd ElAal, H.A. 2008. Attempts to find the best preharvest treatment required for obtaining the optimum marketable fruits and its effect on storage life of 'Manfalouty' pomegranates. I. Evaluating of some soil and foliar treatments on splitting, sunburn, yield and fruit quality. Minia J. Agric. Res. \& Develop, 28(2): 263-283.

Muller, P., Li, X.P. and Niyogi, K. 2001. Nonphotochemical quenching. A response to excess light energy. Physiol., 125: 1558-1566.

Proctor, J.T.A. and Lougheed, E.C. 1976. The effect of covering apples during development. HortSci., 11: 108-109.

Rabinowitch, H.D., Kedar,N. and Budowski, P. 1974. Induction of sunscalddamage in tomatoes under natural and controlled conditions. Scientia Horticulturae, 2: 265-272.

Racskó, J., Thurzó,S., Szabó,Z. and Nyéki, J. 2005. Effect of sunburn on Malus domestica (Borkh.) apples. Gesunde Pflanzen, 57(2-3): 47-52. 
Ritenour, M.A., Kochhar, S., Schrader, L., Hsu, T. and $\mathrm{Ku}, \mathrm{M} .2001$. Characterization of heat shock protein expression in apple peel under field and laboratory conditions. J. American Society for Horticultural Sci., 126: 564-570.

Schrader, L., Zhang, J. and Sun, J. 2003. Envirnomental stresses that cause sunburn of apple. Acta Horticulture, 618: 397-405.

Schrader, L.E. 2011. Scientific basis of a unique formulation for reducing sunburn of fruits. Hort. Sci., 46: 6-11.

Schrader, L.E., Sun, J., Zhang, J., Felicetti, D., and Tian, J. 2008. Heat and light-induced apple skin disorders: causes and prevention. Acta Hort., 772: 51-58.

Schrader, L., Sun, J., Felicetti, D., Seo, J., Jedlow, L. and Zhang, J. 2003b. Stress induced disorders: Effects on apple fruit quality. Washington Tree Fruit Postharvest Conference, 2 - 3 December, Wenatchee, WA; http://postharvest.tfrec.wsu.edu/PC2003A .pdf (Accessed: 21 April 2011).

Schrader, L., Zhang, J. and Sun, J. 2003a. Environmental stresses that cause sunburn of apple. Acta Hort., 618: 397-405.

Schrader, L.E., Zhang, J. and Duplaga, W.K. 2001. Two types of sunburn in apple caused by high fruit surface (peel) temperature. Plant Health Progress Online, doi:10.1094/PHP-2001-1004-01RS.

Schupp, J.R., Fallahi, E. and Chun, J.K.J.O. 2002. Effect of particle film on fruit sunburn maturity and quality of 'Fuji' and 'Honeycrisp' apple. Hort Technol., 12(1): 87-90.

Simpson, J., Rom, C.R. and Patterson, M. 1988. Causes and possible controls of sunburn on apples. Good Fruit Grower, 39(2): 1617.

Singh, G., Nath, V., Pandery, S.D., Ray, P.K. and Singh, H.S. 2012. The Litchi (Food and Agriculture Organization of the United Nations). Pp: 181

Toye, J. 1995. Reflective mulches-New Zealand leads the way. The Orchardist, 68(8): 5860.

Wand, S.J.E., Theron, K.I. Ackerman, J. and Marais, S.J.S. 2006. Harvest and postharvest apple fruit quality following applications of kaolin particle film. South African orchards. Scientia Hort., 107: 271-276.

Ware, W.M. 1932. High temperature injury on the growing apple. Gardners Chron., 92: 287-288.

Warner, G. 1997. Sunburn is a hot topic in orchards of Washington. The Good Fruit Grower, 48(13): 2223.

Werblow, S. 1999. Favorable film. Ore. Farmerstockman (April): 8-10.

Whittaker, E.C. and McDonalds S.L.D. 1941. Prevention of sunscald of deciduous fruit trees in hot climates. Agr. Gaz. N. S. Wales, 52: 231233.

Wunsche, J.N., Lombardini, L. and Greer, D.H 2004. 'Surround' particle film applications-effects on whole canopy physiology of apple. Horticulture, 636: 565-571.

Yuanwen, T. 1992. Antitranspirant and its application to fruit trees. Agr. Res. Arid Areas, 10: 272-278.

Yuri, J.A., Torres, C. and V’asquez, Y.J. 2000. Sunburn on apples. I. Damage evaluation and control methods. Agro-Ciencia, 16(5): 13-21. (In Spanish with English summary).

\section{How to cite this article:}

Narayan Lal and Nisha Sahu. 2017. Management Strategies of sun burn in fruit crops-A review. Int.J.Curr.Microbiol.App.Sci. 6(6): 1126-1138.

doi: https://doi.org/10.20546/ijcmas.2017.606.131 